\title{
Tyrosine hydroxylase gene transfections to different sites of striatum in the rat model of Parkinson's disease
}

\author{
Atso Raasmaja ${ }^{1 *}$, Sarka Lehtonen ${ }^{2}$, Tiina Kääriäinen ${ }^{2}$, Pasi Lampela², Marko Huotari ${ }^{2}$, Anne Lecklin ${ }^{2}$ \\ ${ }^{1}$ Division of Pharmacology \& Toxicology, University of Helsinki, Helsinki, Finland \\ ${ }^{2}$ Department of Pharmacy, University of Eastern Finland, Kuopio, Finland \\ Email: ${ }^{*}$ atso.raasmaja@helsinki.fi
}

Received 28 March 2013; revised 30 April 2013; accepted 15 May 2013

Copyright (C) 2013 Atso Raasmaja et al. This is an open access article distributed under the Creative Commons Attribution License, which permits unrestricted use, distribution, and reproduction in any medium, provided the original work is properly cited.

\section{ABSTRACT}

The use of gene therapy has been intensively studied as a potential method to treat Parkinson's disease (PD) and other degenerative brain diseases. However, the effects of experimental measures and approaches on the outcome of gene delivery or on the physiological state of target tissues have not been analyzed as much and systematically. Therefore, we have infused adenovirus vectors expressing either a therapeutic tyrosine hydroxylase (TH) gene or a lacZ reporter gene into striatum in a rat model of PD. The experimental procedures were tested using the $A d$ lac $Z$ vector in order to optimize concentrations, volumes, infusion speeds and transfection times. The expression of Ad lacZ vector was lower and declined earlier in the lesioned than unlesioned striatum suggesting that the lesion affects on the transfection efficiency and outcome of gene transfection. The effect of three different approaches of Ad TH vector transfection was compared: 1) the delivery of Ad TH gene vector alone into one single site of striatum, 2) the delivery of Ad TH gene vector alone into multiple sites of striatum, and 3) the delivery of Ad TH gene vector into one site of striatum followed by a continuous infusion of tetrahydrobiopterin (BH4) cofactor with a mini pump. There was a small and transient unsignificant decrease in the turning behavior when the Ad TH vector was delivered into one site of the striatum. Simultaneous infusion into several sites or together with BH4 cofactor did not improve more the effect of gene delivery. Thus, although the effects were unsignificant, the Ad TH transfection seemed to decrease the turning behavior in the rat model of PD and the optimal effect was seen at some specific doses and time points. Furthermore, the outcome of gene therapy could depend in addition to the amount and efficacy

${ }^{*}$ Corresponding author. of gene vectors also on the physiological state and experimental strategies.

Keywords: Tyrosine Hydroxylase; Tetrahydrobiopterin; Adenovirus Vector; 6-Hydroxydopamine; Parkinson's Disease; Gene Therapy

\section{INTRODUCTION}

The development of Parkinson's disease (PD) is associated with the degeneration of dopamine producing cells in substantia nigra and the resultant decreases of dopaminergic activity and motor impairment $[1,2]$. Current pharmacological treatment of Parkinson's disease is insufficient, contains serious side effects and even loses its efficiency by time $[3,4]$. As one alternative strategy the use of gene therapy has been intensively studied to improve the treatment of Parkinson's disease [5-8].

A number of gene delivery vectors and therapeutic genes have been used to study the potential of gene delivery in experimental models of Parkinson's disease $[7,8]$. Viral vectors have been more effective and useful than nonviral vectors for in vivo gene transfections despite that they have in general higher toxicity. Viral vectors examined in the study models of Parkinson's disease include e.g. adenovirus, adeno-associated virus and lentivirus vectors. Therapeutic genes which have been used especially to enhance dopamine synthesis are amino acid decarboxylase (AADC), tyrosine hydroxylase (TH) and GTP cyclohydrolase I, and those to improve especially the condition of dopaminergic cells are neurotrophic factor genes as glial cell derived growth factor (GDNF) and neurturin $[7,8]$. In the animal models the use of gene therapy has been efficient, the synthesis of dopamine has increased and the experimental measures and symptoms of Parkinson's disease improved. However, as far the results from clinical studies have been rather inconsistent although promising. 
In the present work, we have used adenovirus (Ad) vectors to examine the striatal TH gene delivery in a rat model of PD. Experimental conditions were followed with the lacZ reporter gene in order to optimize the amounts, volumes and distribution of the gene transfection. The behavioural effect of TH gene transfection was estimated, when the Ad TH vector was delivered into single or multiple sites of striatum or when the tetrahydrobiopterin (BH4) cofactor was infused continuously after $\mathrm{TH}$ gene transfection.

\section{MATERIAL AND METHODS}

\subsection{Drugs}

6-Hydroxydopamine $\mathrm{HCl}$, apomorphine $\mathrm{HCl}$ and tetrahydrobiopterin were obtained from Sigma-Aldrich Co. (St. Louis, MO, USA). Lidocaine was purchased from Orion Pharma (Espoo, Finland), chloral hydrate from Merck KgaA (Darmstadt, Germany) and buprenorphine from Schering-Plough (Kenilworth, NJ, USA). If not otherwise mentioned, all the drugs were dissolved in $0.9 \%$ $\mathrm{NaCl}$. The doses of drugs refer to the respective free bases.

\subsection{Animals and Housing}

Male Wistar rats were supplied by the National Laboratory Animal Center, University of Eastern Finland. At the time of the lesioning, the rats weighed $190-280 \mathrm{~g}$. Before the surgery, the rats were housed in stainless steel cages in groups of $4-5$ rats/cage and kept on a 12/12 h light/dark cycle (lights on at 07:00 a.m.) at an ambient temperature of $22^{\circ} \mathrm{C} \pm 1^{\circ} \mathrm{C}$. Pelleted food (Lactamin R36, Lactamin AB, Södertälje, Sweden) with tap water were available ad libitum. After the surgery, the animals were kept in individual stainless steel cages for one week for recovery and subsequently in groups of 3 - 4 rats. All the experiments were carried out between 7:00 a.m. and 7:00 p.m. All procedures were conducted according to European Community Guidelines for the use of experimental animals and reviewed by the Animal Ethics Committee at the University of Kuopio in conformance with current legislation and approved by the local Provincial Government.

\subsection{Lesion of the Right Medial Forebrain Bundle}

The lesion procedure was performed according to Ungerstedt [9] with minor modifications as earlier described [10,11]. 6-OHDA was dissolved in isotonic $\mathrm{NaCl}$ solution containing $0.2 \mathrm{mg} / \mathrm{ml}$ of ascorbic acid $(2.5 \mu \mathrm{g}$ of 6OHDA in $1 \mu \mathrm{l})$. The volume of the 6-OHDA-infusion was $4 \mu 1$ and it was dispensed over an 8 min period. The coordinates for the final infusion site in the right medial forebrain bundle (MFB) near substantia nigra measured from bregma were [AP -4.4, L -1.2, DV -8.3] [12]. Before the surgery, lidocaine was applied to the scalp and to the surface of the skull as local anesthesia to relieve postoperative pain. Also a single dose of buprenorphine (0.02 $\mathrm{mg} / \mathrm{kg}$ ) was given subcutaneously after the surgery.

\subsection{Testing of Successfulness of 6-OHDA-Lesion}

Following a 2-week recovery period, rats were tested for apomorphine-induced $(0.1 \mathrm{mg} / \mathrm{kg}$ subcutaneously) rotational behavior to assess the successfulness of the lesion using an automatic 8-channel rotometer (Coulbourn Instruments, Inc., Allentown, PA, USA). The rotometer registered ipsilateral and contralateral full circlings separately. The rats showing $>100$ full contralateral circlings in a 60-min test session were accepted for further tests.

\subsection{Adenovirus Vector}

Replication-deficient E1-E3-deleted adenovirus (serotype 5) expressing specific transgenes have been used for these studies $[13,14]$. The distribution and efficiency of gene transfection was estimated as beta galactosidase activity using X-gal histochemistry. To optimize the transfection conditions of the adenovirus-mediated gene transfection in the striatum, the dose-dependence $\left(10^{5}, 10^{6}\right.$, $10^{7}, 10^{8}$ and $10^{9} \mathrm{pfu}$ ), the effects of transfection volumes $\left(1,5,10\right.$ and $\left.20 \mu \mathrm{l} ; 10^{8} \mathrm{pfu}\right)$ and time course $(3,7$ and 14 days) were examined. Coordinates of infusion sites, and titers and volumes of injected virus varied for individual experiments.

\subsection{Administration of the Ad TH Gene Vector into 6-OHDA-Lesioned Striatum}

Part 1. Transfection of TH gene into one site of striatum. After the apomorphine test, successfully lesioned rats were randomly divided into six treatment groups $(n=6$ in each group). For the vector administration into the 6OHDA-lesioned striatum, the rats were anesthetized with chloral hydrate $(350 \mathrm{mg} / \mathrm{kg}$, i.p.). A stainless steel guide cannula (made from a $23 \mathrm{G}$ needle) was lowered $2.0 \mathrm{~mm}$ above the infusion site. An infusion needle (made from a $30 \mathrm{G}$ needle) was lowered $2.0 \mathrm{~mm}$ below the tip of the guide cannula. The needle was connected to PE10-type tubing with a Hamilton microsyringe, and run by a motor-driven slow-motion syringe pump (Univentor 864, AgnTho's AB, Lidingö, Sweden). The infusion of vector (Ad TH-vector at doses of $10^{6}-10^{9} \mathrm{pfu} / \mathrm{ml}$ or Ad lacZvector at a dose of $10^{7} \mathrm{pfu} / \mathrm{ml}$ ) or vehicle solution $(\mathrm{NaCl})$ was given into one site of the lesioned striatum at the final coordinates measured from bregma (AP +0.2 , L $-2.8, \mathrm{DV}-2.5$ ) [5]. The infusion volume was $6.0 \mu 1$ and it was infused over a 6 -min period at a flow rate of 0.5 
$\mu \mathrm{l} / \mathrm{min}$. The needle was retained in position for $4 \mathrm{~min}$ after the infusion.

Part 2. Transfection of $\mathrm{TH}$ gene into four sites of striatum. There were five treatment groups of 6-OHDAlesioned rats ( $\mathrm{n}=6$ in each group). The experimental protocol was the same as in Part 1 except for the infusion sites and the infusion parameters. The vector infusion was given into four sites of the lesioned striatum. For the quadruple infusion, four needles (29G) were lowered directly to the infusion sites using a custom-made infusion instrument where the needles were fixed to a block that was used as a single unit. Each needle was connected to tubing with a microsyringe and run by a motor-driven slow-motion syringe pump. The final coordinates for intrastriatal vector infusion (Ad TH-vector at doses of $10^{5}-10^{7} \mathrm{pfu} / \mathrm{ml}$ or Ad lacZ-vector at a dose of $10^{7} \mathrm{pfu} / \mathrm{ml}$ ) were measured from bregma (AP $1.2, \mathrm{~L}-2.4$, DV -6.0); (AP 0.5, L -3.5, DV -7.0); (AP 0.0, L -2.2, DV -6.5) and (AP - 0.8, L 4.0, DV -6.5) [5]. The volume of the infusion was $3.0 \mu \mathrm{l}$ and it was infused into each location over a $6-\mathrm{min}$ period at a flow rate of $1.0 \mu \mathrm{l} / \mathrm{min}$. The needles were retained in position for $4 \mathrm{~min}$ after the infusion.

Part 3. Transfection of TH into one site of striatum followed by a continuous infusion of $\mathrm{BH} 4$ cofactor. $\mathrm{BH} 4$ was dissolved in isotonic saline containing $1 \mathrm{mg} / \mathrm{ml}$ ascorbic acid. Osmotic minipumps (Alzet Model 2002, Alza Co. Palo Alto, CA, USA) were filled with $0.02 \mathrm{mM}$, $0.2 \mathrm{mM}$ or $2.0 \mathrm{mM} \mathrm{BH} 4$ or vehicle and then incubated at $37^{\circ} \mathrm{C}$ overnight in isotonic saline before implantation. In the morning of the surgery, rats were randomly divided into five treatment groups $(\mathrm{n}=8)$ and they were anesthetized with chloral hydrate $(350 \mathrm{mg} / \mathrm{kg}$, i.p.). Ad TH at a dose $1 \times 10^{7} \mathrm{pfu} / \mathrm{rat}$ or saline were infused into one site of the lesioned striatum at the final coordinates measured from bregma (AP +0.2, L - 2.8, DV -2.5) [5] as described in Part 1. After this, osmotic minipumps containing BH4 or vehicle were implanted subcutaneously. Each pump was attached to a catheter with a custom-made instrument with an infusion needle implanted surgically under a stereotaxic device, being secured to the skull using stainless steel screws and dental cement enabling local BH4 infusions at a rate of $0.5 \mu 1 / \mathrm{min}$ for 14 days.

\subsection{Testing of Rotational Behavior after the Intrastriatal Infusion of Gene Vector}

The rotation tests started one week after intrastriatal vector infusion and continued at one-week intervals until week 8 and week 9 for single and quadruple infusions, respectively. The rotational test was performed as described when testing the successfulness of 6-OHDA-lesion. In each group, the results were compared against the result of preoperative apomorphine-induced rotation test of each group i.e. that performed just before the infusion of the gene vector. After the last rotation test, the rats were deeply anesthetized with chloral hydrate and transcardially perfused with phosphate buffer saline (PBS), followed by $4 \%$ paraformaldehyde (Merck, Darmstadt, Germany) in phosphate buffer $\mathrm{pH}$ 7.4. The brains were removed, postfixed for $4 \mathrm{~h}$ and stored at $-70^{\circ} \mathrm{C}$.

\subsection{Statistical Analysis}

The mean of the total amount of contralateral rotations in preoperative test performed prior to the gene vector infusion of each group was calculated and amount of contralateral rotation after the infusion in each test were expressed as a percentage of this value $(=100 \%)$. Group results are shown as means \pm SEM. The effect of gene vector treatment vs. apomorphine-induced rotational behavior was analyzed by using one-way analysis of variance (ANOVA) followed by Tukey's post hoc test. Statistical analyses were performed with GraphPad Prism 4.03 software (GraphPad Software, San Diego, CA, USA). The criterion for statistical significance was $\mathrm{p}<$ 0.05 .

\section{RESULTS AND DISCUSSION}

Gene therapy has been developed as a novel approach to the treatment of neurological diseases, and e.g. adenovirus-mediated gene therapy has been tested as a potential treatment for Parkinson's disease in animal models. It is suggested that the outcome of gene transfection can depend on the physiological state of target cells and tissue $[15,16]$. It is possible that in the experimental models of PD the success of gene therapy could be affected by the condition of nigrostriatal cells, too.

In preliminary experiments we compared the efficiency, maintenance and distribution of the Ad lacZ gene transfection between the intact and lesioned striatum (Table 1; Figure 1). The unilateral lesion of the rat striatum was induced by an injection of 6-OHDA into the right MFB causing a site-specific degeneration of nigrostriatal nerve fibers leading from the substantia nigra to striatum. Two to three weeks after that, the unlesioned and lesioned striatum was transfected in parallel in the same rats.

Table 1. Comparison of Ad lacZ expression levels in the intact and lesioned rat striatum.

\begin{tabular}{ccc}
\hline & Intact & Lesioned \\
\hline Day 3 & +++++ & ++++ \\
Day 7 & ++++ & +++ \\
Day 14 & ++++ & +++ \\
\hline
\end{tabular}

Estimations are from gene transfections made with different volumes $(n=4$ - 5) and time points $(n=4-5)$. 
I

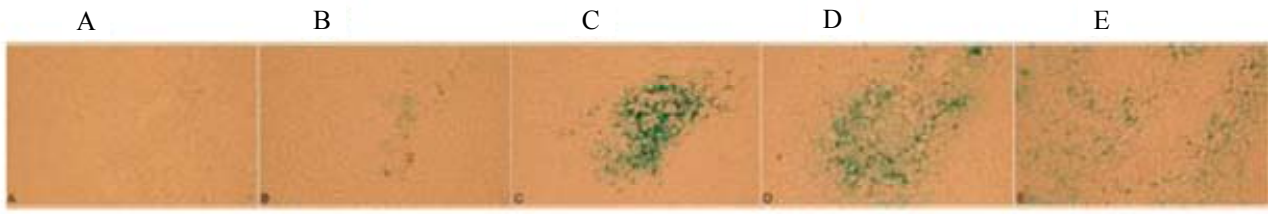

II A B C D
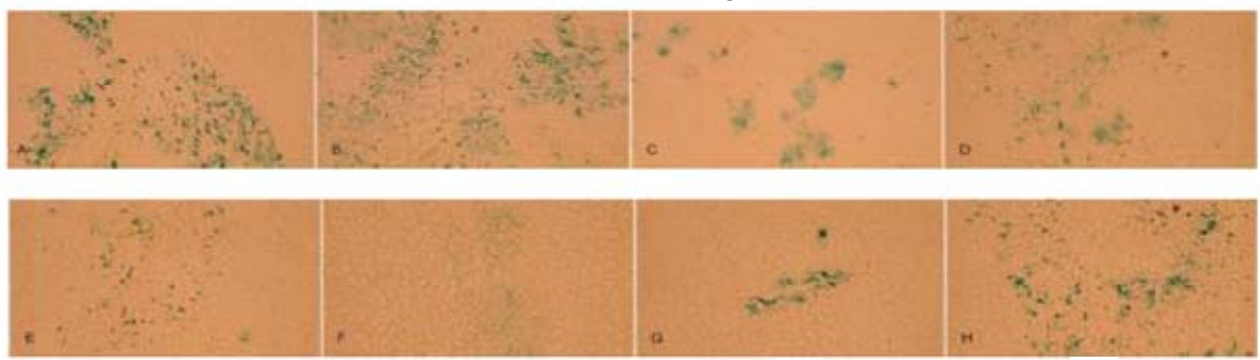

$\mathrm{E}$

III

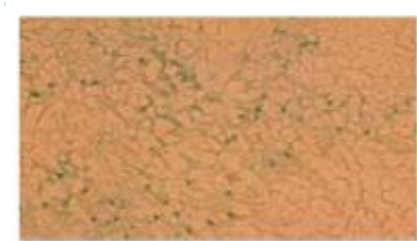

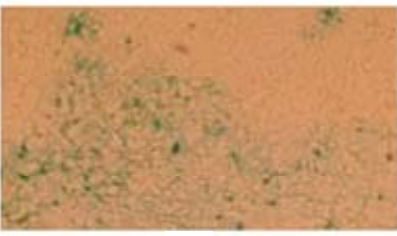

D
F

B
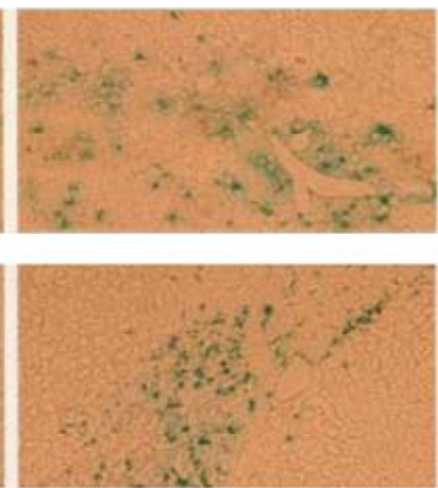

E
G

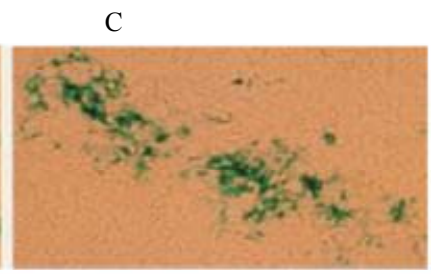

Figure 1. Doses (I A-E) Dose-dependence of Ad lacZ gene transfection in the striatum of unlesioned control rats analysed as a beta galactosidase histochemistry at 7 days from gene delivery. The infusion volume was $3 \mu \mathrm{l}$ and the titers were $10^{5}, 10^{6}, 10^{7}, 10^{8}$ and $10^{9}$ pfu for A, B, C, D and E, respectively. Volumes (II A-F) The effect of different volumes of Ad lacZ vector $\left(10^{8} \mathrm{pfu}\right)$ on the gene expression one week after gene transfection. The infusion volumes were $1,5,10$ and $20 \mu \mathrm{l}$ in A, B, C and D or E, F, G and $\mathrm{H}$ for the unlesioned or lesioned rat striatum, respectively. Maintenance (III A-F) Time course of Ad lacZ $\left(10^{8} \mathrm{pfu}\right)$ vector expression in the unlesioned $(\mathrm{A}, \mathrm{B}, \mathrm{C})$ and lesioned $(\mathrm{D}, \mathrm{E}, \mathrm{F})$ rat striatumat day 3,7 and 14 after the gene delivery. The results are representative from three to five gene transfections.

The dose-dependence of Ad lacZ vector $\left(10^{5}-10^{9} \mathrm{pfu}\right)$ delivery was tested in the healthy unlesioned rats by infusing the vector directly to the rat striatum with a microdialysis pump using a flow rate of $0.5 \mu \mathrm{l} / \mathrm{min}$ (Figure 1). When different infusion volumes were tested, the adenovirus-mediated lacZ gene transfection was associated with significant expression of beta galactosidase in both intact and lesioned striata.

The maintenance of transfection and expression was followed for 1, 3, 5, 7 and 14 days. The expression of transgene was somewhat less stable in the lesioned than intact site. It has been reported earlier that the expression of adenoviral lacZ gene was different between ischemic and reperfused rat brains [17]. Similarly the lesion model used here seemed to weaken the efficiency and expres- sion of gene transfection. Thus, in general the Ad lacZ gene transfection was efficient at both sites, although it was often more successful, intensive and wider at the healthy than at the lesioned striatum as summarized in Table 1.

The effects of three different strategies were compared for the Ad TH gene transfection in the rat model of PD: 1) the delivery of Ad TH gene vector alone into one single site of striatum (Figure 2), 2) the delivery of Ad TH gene vector alone into multiple sites of striatum (Figure 3), and 3) the delivery of Ad TH gene vector into one site of striatum followed by a continuous infusion of BH4 cofactor with a mini pump (Figure 4). There was a small but transient and unsignificant decrease in the turning behavior when the Ad $\mathrm{TH}$ vector was delivered into one 
1 week

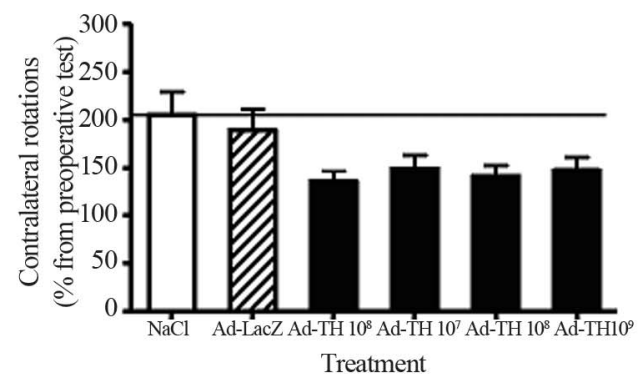

5 week

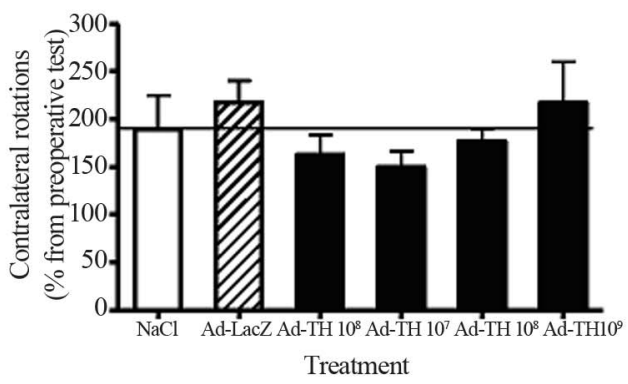

3 week

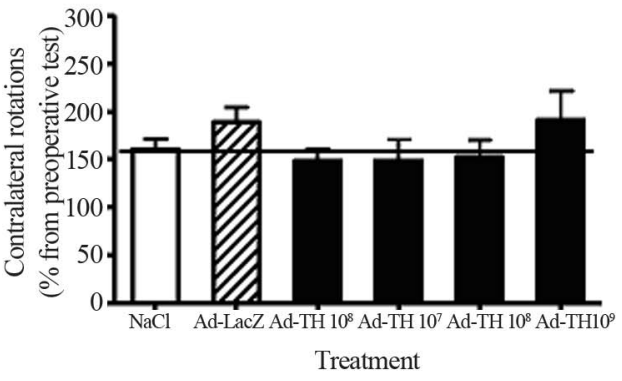

8 week

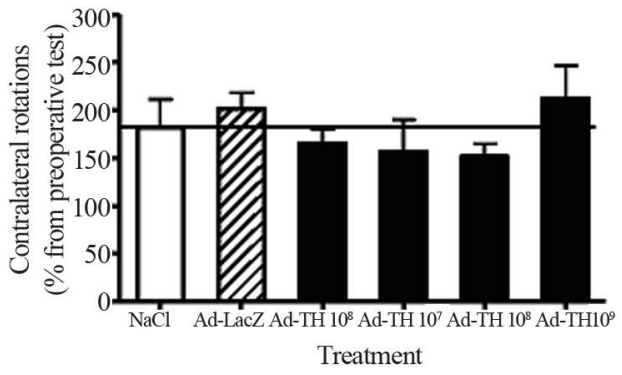

Figure 2. The TH gene delivery into one site of striatum in the rat PD model. Apomorphine-induced $(0.1 \mathrm{mg} / \mathrm{kg}$, s.c.) rotational behavior was followed in the unilaterally 6-OHDA-lesioned rats. Rats received vehicle solution $(\mathrm{NaCl}), \mathrm{Ad}$ lac $\mathrm{Z}$ vector or $\mathrm{Ad} \mathrm{TH}$ vector into one site of lesioned striatum as a single infusion. Values are means \pm SEM of contralateral rotations in each test as percentage of preoperative test performed before intrastriatal infusion $(n=5-6)$.
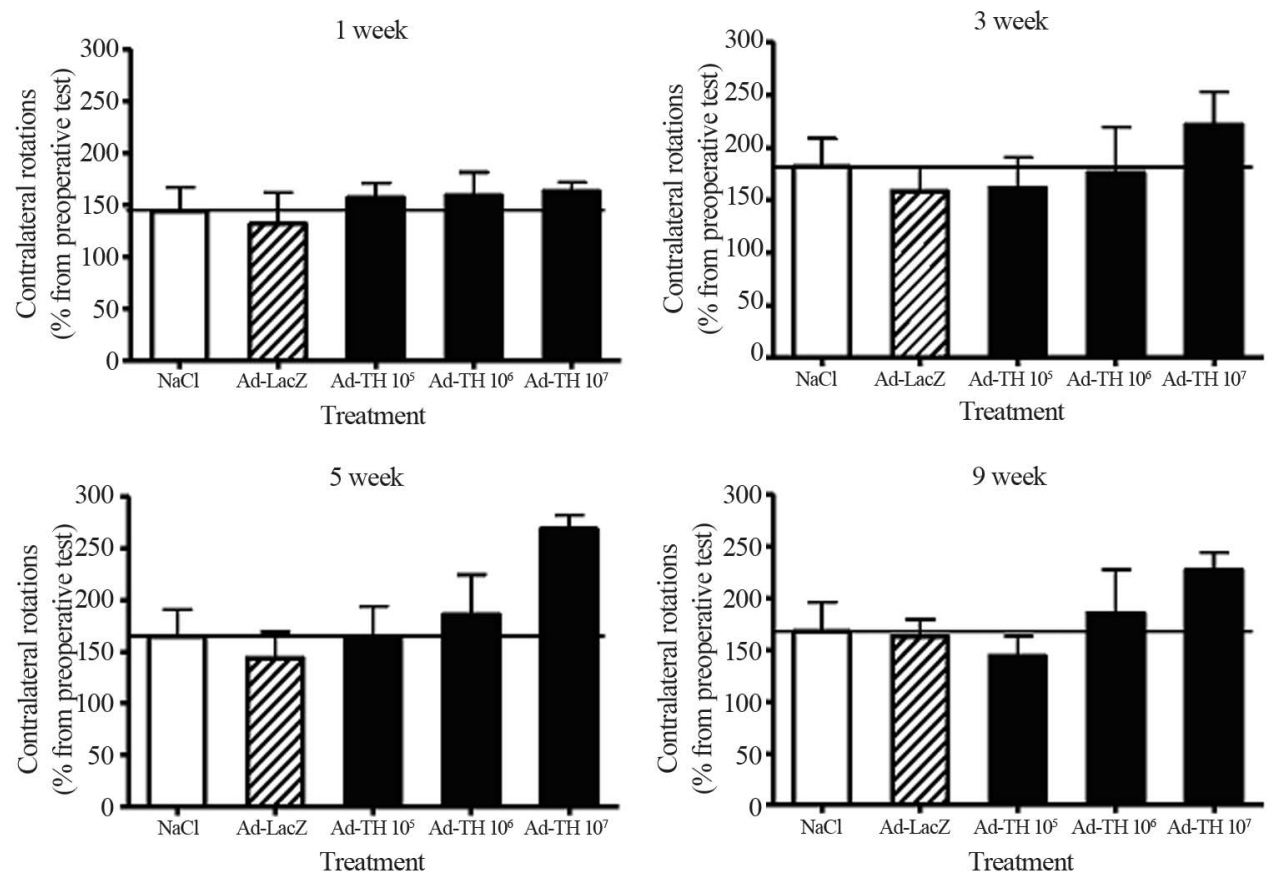

Figure 3. The TH gene delivery into four sites of striatum in the rat PD model. Apomorphine-induced $(0.1 \mathrm{mg} / \mathrm{kg}$, s.c.) rotational behavior was followed in the unilaterally 6-OHDA-lesioned rats. Rats received vehicle solution $(\mathrm{NaCl}), \mathrm{Ad} \mathrm{lacZ}$ vector or $\mathrm{Ad} \mathrm{TH}$ vector into four sites of the lesioned striatum as a single infusion. Values are expressed as percentage of means \pm SEM of contralateral rotations as compared to the rotations in preoperative test performed before intrastriatal infusion (n $=5-6)$. 

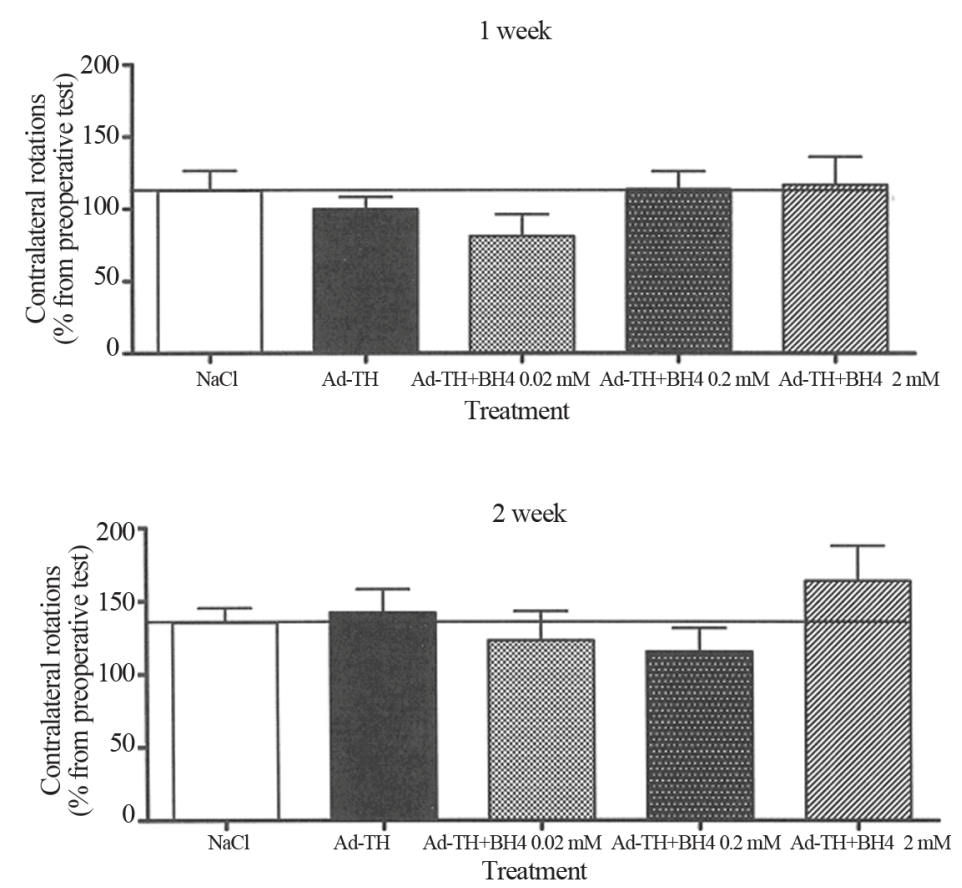

Figure 4. The TH gene delivery into one site of striatum followed by a continuous infusion of $\mathrm{BH} 4$ cofactor in the rat PD model. Apomorphine-induced $(0.1 \mathrm{mg} / \mathrm{kg}$, s.c.) rotational behavior was followed in the unilaterally 6-OHDA-lesioned rats. Rats received $\mathrm{Ad} \mathrm{TH}$ or $\mathrm{NaCl}$ into one site of the lesioned striatum as a single infusion. After this, BH4 at concentrations of $0.02 \mathrm{mM}, 0.2 \mathrm{mM}, 2.0 \mathrm{mM}$ or vehicle were given as continuous infusions (for two weeks) into lesioned striatum using osmotic minipumps. Values are means \pm SEM of contralateral rotations $(n=6-8)$.

site of the striatum.

Simultaneous infusion into several sites or together with $\mathrm{BH} 4$ cofactor did not improve the effect of gene delivery more than seen for single infusions. Although the effects were not significant, the Ad TH transfection seemed to decrease the turning behavior and the optimal effect was obtained at certain doses and time points. The outcome of gene therapy seemed to depend on the amount and efficacy of gene vector. The best response was seen at an optimal vector amount perhaps due to the physiological state of target cells and tissue.

A so called full lesion of MFB has been used in this work and it is known to cause a very strong degeneration of dopaminergic neurons. Therefore, it would be expected that the treatments of this type of lesion should not be as successful as those of milder lesions. Also high amounts and titers of viral vectors may not be most optimal and effective but even harmful and destructive. This is supported in that the improvements were seen with some optimal amounts and titers whereas lower and higher amounts were not as efficient.

Minor beneficial effects have been received with the adenovirus vector mediated gene transfections in the experimental PD models also earlier. For example, the
Ad TH gene transfection has been earlier studied in the rat model of PD [18], and it was shown that when the effects of striatal AdTH gene transfections were tested, the apomorphine-induced turning was decreased by $30 \%$ and $22 \%$ at the days 7 and 14 after the gene therapy, respectively. Present results are in agreement with this report. In our study there was a decrease of $30 \%$ at 1 week and $20 \%$ at 5 weeks.

For a successful gene therapy the target cells and tissues should be able to appropriately express the therapeutic genes and synthesize functionally active proteins. Earlier a dissociative expression of Ad lacZ gene transfection was found in ischemic rat brain [17]. It has been reported by others, too, that the transfection efficiency and transgene expression can be dependent on the lesion and tissue $[19,20]$. Therefore, it is likely that the transfection efficiency of gene vectors in the target cells and tissues would be affected by methodological parameters and physiological conditions.

Here, the animal model was based on the unilateral injection of the dopaminergic neurotoxin 6-OHDA into the MFB near the substantia nigra leading to a full chemical lesion of dopaminergic cells. It is possible that the lack of a significant improvement in the present experi- 
Table 2. Experimental overview of TH gene therapy in the rat model of Parkinson's disease.

\begin{tabular}{|c|c|c|c|}
\hline Parameter & Method & Object & Significance \\
\hline Type of TH genes & Isolation of cDNAs & $\begin{array}{l}\text { Rat TH1 } \\
\text { Human TH1 and TH2 }\end{array}$ & Availability of therapeutic genes \\
\hline Expression of TH genes & $\begin{array}{l}\text { Cloning to viral and nonviral } \\
\text { expression systems } \\
\text { Type of vectors and expression } \\
\text { plasmids }\end{array}$ & $\begin{array}{l}\text { Recombinant viruses } \\
\text { Regulation of expression }\end{array}$ & $\begin{array}{l}\text { Expression of therapeutic genes } \\
\text { Maintenance } \\
\text { Elimination }\end{array}$ \\
\hline Delivery of cDNA & $\begin{array}{l}\text { Ex vivo strategy } \\
\text { In vivo strategy }\end{array}$ & $\begin{array}{l}\text { Genetically modified transplants } \\
\text { Direct gene transfection in the brain }\end{array}$ & $\begin{array}{l}\text { Incorporation to target cells and tissues } \\
\text { Delivery to therapeutic site and tissue }\end{array}$ \\
\hline Transcription of gene & $\begin{array}{l}\text { rtPCR } \\
\text { Northern hybridization } \\
\text { In situ hybridization }\end{array}$ & $\begin{array}{l}\text { Identification of TH mRNA } \\
\text { Quantification of TH mRNA } \\
\text { Localization of TH mRNA }\end{array}$ & $\begin{array}{l}\text { Presence of TH mRNA } \\
\text { Amount of TH mRNA } \\
\text { Type of TH expressing cells }\end{array}$ \\
\hline Translation of protein & $\begin{array}{l}\text { Western hybridization } \\
\text { Immunohistochemistry } \\
\text { Enzyme assay }\end{array}$ & $\begin{array}{l}\text { Quantification of TH protein } \\
\text { Localization of TH protein } \\
\text { Activity of TH enzyme }\end{array}$ & $\begin{array}{l}\text { Amount of TH protein } \\
\text { Type of TH producing cells } \\
\text { Conversion of 1-DOPA by TH enzyme }\end{array}$ \\
\hline Physiological response & $\begin{array}{l}\text { Radioimmunoassay } \\
\text { HPLC }\end{array}$ & Amount of neurotransmitters & $\begin{array}{l}\text { Synthesis of DA } \\
\text { Dopaminergic activity }\end{array}$ \\
\hline Behavioral response & $\begin{array}{l}\text { Turning model } \\
\text { 6-OHDA }\end{array}$ & $\begin{array}{l}\text { Apo-induced rotation } \\
\text { Amp-induced rotation }\end{array}$ & $\begin{array}{l}\text { Effect of turning behavior in vivo } \\
\text { Improvement by gene therapy }\end{array}$ \\
\hline
\end{tabular}

ments was associated with this full lesion model and substantial degeneration of target cells. This is supported by the less successful Ad lacZ vector delivery into the lesioned than intact site.

It is difficult to compare the results of gene transfections in the animal models of PD between different laboratories. The efficiency can vary due to a number of experimental factors such as site and degree of lesions, designs and time schedules, volumes, titers and infusion rates, or promoters and other vector structures. If the condition of target tissue would affect on the transfection and expression of the vector, especially the degree and site of the lesion would be critical for the outcome. Therefore, it would be useful to follow the effects of gene therapy treatments on the physiological conditions in more detail. Different approaches could be chosen to estimate the consequences of gene transfections in the experimental models of PD and other disease models including analysis of specific cellular and tissue factors as proposed in Table 2.

Thus, the effect of Ad TH gene therapy was small and temporary and the effects of different strategies were similar. In general the results were in agreement with earlier studies. It is suggested that the minor effects by the striatal Ad TH gene transfections were due to the full 6-OHDA lesion model used in the present study. Therefore, it is apparently important to compare and estimate the outcome of gene delivery with the degree of disease and state of target tissue.

\section{REFERENCES}

[1] Hornykiewicz, O. (1982) Brain neurotransmitter changes in Parkinson's disease. In: Marsden, C.D. and Fahn, S. Eds., Movement disorders, Butterworth Scientific, London, 41-58.

[2] Hornykiewicz, O., Kish, S., Becker, L., Farley, I. and Shannak, K. (1986) Brain neurotransmitters in dystonia musculorum deformans. New England Journal of Medicine, 315, 347-353. doi:10.1056/NEJM198608073150602

[3] Birkmayer, W. and Hornykiewicz, O. (1961) Der L-3,4-Dioxyphenylalanin (=DOPA)-Effekt bei der Parkinson-Akinse. Wiener KlinischeWochenschrift, 73, 787-788.

[4] Chase, T., Engber, T. and Mouradian, M. (1994) Palliative and prophylactic benefits of continuously administered dopaminomimetics in Parkinson's disease. Neurology, 44, S15-S18.

[5] Elsworth, J. and Roth, R. (1997) Dopamine synthesis, uptake, metabolism and receptors: Relevance to gene therapy of Parkinson's disease. Experimental Neurology, 144, 4-9. doi:10.1006/exnr.1996.6379

[6] Stern, M. and Freese, A. (1997) Parkinson's disease: The case for novel treatment strategies. Experimental Neurology, 144, 2-3. doi:10.1006/exnr.1996.6378

[7] Fiancada, M., Forsayeth, J. and Bankiewicz, K. (2008) Current status of gene therapy trials for Parkinson's disease. Experimental Neurology, 209, 51-57. doi:10.1016/j.expneurol.2007.08.009

[8] Feng, L.R. and Maquire-Zeiss, K.A. (2010) Gene therapy in Parkinson's disease: Rationale and current status. CNC Drugs, 24, 177-192. doi:10.2165/11533740-000000000-00000

[9] Ungerstedt, U. (1971) Postsynaptic supersensitivity after 6hydroxy-dopamine induced degeneration of the nigrostriatal dopamine system. Acta Physiologica Scandinavica Supplements, 367, 69-93.

[10] Huotari, M., Kukkonen, K., Liikka, N., Potasev, T., Raasmaja, A. and Männistö, P.T. (2000) Effects of hista- 
mine H3-ligands on the levodopa-induced turning behavior of hemiparkinsonian rats. Parkinsonism and Related Disorders, 6, 159-164. doi:10.1016/S1353-8020(00)00007-9

[11] Törnwall, M. and Männistö, P.T. (1993) Effects of three types of catechol O-methylation inhibitors on L-3,4-dihydroxyphenylalanine-induced circling behaviour in rats. European Journal of Pharmacology, 250, 77-84. doi:10.1016/0014-2999(93)90623-P

[12] Paxinos, G. and Watson, C. (1986) The Rat Brain in Stereotaxic Coordinates. Academic Press, New York.

[13] Laitinen, M., Mäkinen, K., Manninen, H., Matsi, P., Kossila, M., Agrawal, R.S., Pakkanen, T., Luoma, J.S., Viita, H., Hartikainen, J., Alhava, E., Laakso, M. and Ylä-Herttuala, S. (1998) Adenovirus-mediated Gene Transfer to Lower Limb Artery of Patients with Chronic Critical Leg Ischemia. Human Gene Therapy, 9, 1481-1486. doi:10.1089/hum.1998.9.10-1481

[14] Puumalainen, A.M., Vapalahti, M., Agrawal, R.S., Kossila, M., Laukkanen, J., Lehtolainen, P., Viita, H., Paljärvi, L., Vanninen, R. and Ylä-Herttuala, S. (1998) Beta-galactosidase gene transfer to human malignant glioma in vivo using replication-deficient retroviruses and adenoviruses. Human Gene Therapy, 9, 1769-1774.

[15] McMenamin, M.M., Lantos, T., Carter, E.E., Hamilton, L., Charlton, H.M., Gonzalez, S.C. and Wood, M.J.A. (2004) Neuropathological consequences of delivering an adenoviral vector in the rat brain. Journal of Gene Medicine, 6, 740-750. doi:10.1002/jgm.564

[16] Peltekian, E., Parrish, E., Bouchard, C., Peschanski, M. and Lisovovski, F. (1997) Adenovirus-mediated gene transfer to the brain: Methodological assessment. Journal of Neuroscience Methods, 71, 77-84. doi:10.1016/S0165-0270(96)00128-8

[17] Abe, K., Setoguchi, Y., Hayashi, T. and Itoyama. (1997) Dissociative expression of adenoviral-mediated E. coli $\mathrm{LacZ}$ gene between ischemic and reperfused rat brains. Neuroscience Letters, 226, 53-56. doi:10.1016/S0304-3940(97)00243-7

[18] Horellou, P., Vigne, E., Castel, M.N., Barnéoud, P., Colin P., Perricaudet, M., Delaère and Mallet, J. (1994) Direct intracerebral gene transfer of an adenoviral vector expressing tyrosine hydroxylase in a rat model of Parkinson's disease. Neuro Report, 6, 49-53. doi:10.1097/00001756-199412300-00014

[19] Cieselska, A., Mittermeyer, G., Hadaczek, P., Forsayeth, J. and Bankiewicz, S. (2011) Anterograde axonal transport of AAV2-GDNF in rat basal ganglia. Molecular Therapy, 19, 922-927. doi:10.1038/mt.2010.248

[20] Flotte, T.R., Frederickson, R.M., Lowenstein, P.R. and Mueller, C. (2011) Moving forward toward a cure for parkinson's: neuropathology of the nigrostriatal pathway determines the location of growth factor delivery. Molecular Therapy, 19, 827-829. doi:10.1038/mt.2011.76 